\title{
AFIKS PEMBENTUK NOMINA DALAM BAHASA BANJAR
}

\author{
Akhmad Humaidi dan Ahmad HB \\ Pendidikan Bahasa dan Sastra Indonesia \\ STKIP PGRI Banjarmasin \\ Jalan Sultan Adam, Komplek H. Iyus, No. 18 RT.23 Banjarmasin, \\ Kalimantan Selatan. Kode pos 70121 \\ email: humaidi.a@stkipjm.ac.id
}

\begin{abstract}
Abstrak
Pembentukan nomina atau nominalisasi melalui afiksasi merupakan fenomena yang penting karena proses ini sering terjadi dalam berbagai bahasa termasuk bahasa Banjar. Namun, pemahaman terhadap bentuk ini belum dikuasai karena konsep ini tidak akrab dalam kajian morfologi di Indonesia. Penelitian ini bertujuan untuk mendeskripsikan sistem morfologis dalam nominalisasi bahasa Banjar dari verba, numeralia, adjektiva, dan adverbia. Sumber data dalam penelitian ini berasal dari data lisan dan tulis. Data lisan berasal dari informan yang merupakan penutur asli bahasa Banjar, sedangkan data tulis berasal dari teks berbahasa Banjar yang diambil dari berbagai sumber, sepertibuku tata bahasa, kamus, dan dokumen berbahasa Banjar.Penelitian ini menemukan bahwa afiks yang berperan dalam nominalisasi verba berjumlah lima buah, yaitu prefiks pa- dan ka-, sufiks -an, dan konfiks ka-an dan sa-an, sedangkan afiks yang berperan dalam nominalisasi numeralia berjumlah empat buah, yaitu sufiks -an dan konfiks ka-nya, sa-an, dan saan-nya. Adapun afiks yang menurunkan adjektiva dan adverbia menjadi nomina hanya satu afiks masing-masing, yaitu prefiks pa- pada adjektiva dan konfiks sa-an pada adverbia.
\end{abstract}

Kata kunci: afiks, nomina, bahasa Banjar

\section{Pendahuluan}

Kelas kata sebagai bagian dalam kajian morfologi, khususnya nomina merupakan sebuah fenomena yang penting dan sering mendapat perhatian dari para ahli bahasa. Pembentukan nomina senantiasa muncul dalam kehidupan sehari-hari dalam bahasa manapun baik ragam lisan maupun ragam tulis. Bahasa Indonesia sebagai bahasa nasional yang telah dikodifikasi dengan baik sekalipun masih menghadapi banyak masalah dalam hal pembentukan nomina. Salah satunya ialah belum ada kesatubahasaan tentang konsepsi dasar nominalisasi itu sendiri (Suhardi, 1984: 190).Padahal, nominalisasi memiliki sejumlah keuntungan, seperti meningkatkan makna tekstual, memaksimalkan potensi informasi, menghilangkan makna eksperiensial, abstraksi aktivitas, dan perubahan dari aktivitas menjadi entitas(Garnida \& Mirahayuni, 2012: 1)

Selain itu, praktik penggunaan nominalisasi pada media massa menunjukkan kemampuannya mengeksklusi suatu aktor. Penelitian Bustam \& Juanda(2014: 195)menunjukkan bahwa proses eksklusi akibat nominalisasi terjadi pada The Jakarta Post dengan objek berita perseteruan KPK 
dan polisi. Nominalisaisi membuat Polri "keluar" dari pemberitaan agar perhatian pembaca lebih ditujukan kepada aktor lainnya (korban), yaitu KPK.

Sayangnya, nominalisasi belum dipahami dengan baik oleh masyarakat Indonesia, khususnya pelajar. Fatonah (2014: 87) menemukan bahwa pemahaman siswa terhadap nominalisasi berada pada tingkat menengah, yaitu 65\%.Dengan kata lain, tingkatan pemahaman terhadap nominalisasi ini tidak cukup memadai untuk memahami teks ilmiah.Sebenarnya, kesadaran terhadap fungsi pola nominalisasi dapat menyatukan banyak informasi dalam klausa yang lebih sedikit dan meningkatkan muatan informasi dalam teks, mengekspresikan kekhususan, mengelaborasi dan menjelaskan konsep, membantu pelajar memahami tulisan akademik, dan menafsirkan pengetahuan akademik dengan gaya yang lebih padat (Jalilifar, White, \& Malekizadeh, 2017: 16).

Permasalahan ini tidak mengherankan karena konsep perubahan kelas kata berupa infleksi dan derivasi berasal dari kajian bahasa-bahasa Indo Eropa yang tergolong bahasa flekskai atau infleksi, sedangkan bahasa-bahasa di Indonesiatergolong sebagai bahasa aglutinasi yang lebih sulit dipisahkan secara tegas. Sistem aglutinasi adalah sistem bahasa yang proses pembentukan unsurunsurnya dilakukan dengan cara menempelkan unsur atau bentuk lainnya. Perbedaan sistem afiks ini yang menyebabkan pembahasan mengenai hal ini kurang akrab dalam pembahasan kajian morfologi di Indonesia.

Bahasa Banjar sebagai salah satu bahasa di Indonesia juga mengalami nominalisasi atau pembentukan kelas kata menjadi nomina. Penurunan nomina dalam bahasa Banjar didominasi oleh afiksasi sebagaimana bahasa-bahasa lain di Indonesia, seperti bahasa Gayo yang berasal dari proses afiksasi berdasarkan bentuk dasar adjektiva dan verba (Zainuddin, 2016: 110), bahasa Buol yang berasal dari pelekatan afiks dan reduplikasi pada verba yang akan dinominalisasi dan makna verba yang telah dinominalisasi(Zakaria, 2018: 131), atau bahasa Bali yang berasal dari afiksasi, pemajemukan, perulangan,dan turunan dari klausa(Saryana, 2017). Hal ini menunjukkan bahwa penurunan nomina melalui afiks tidak bisa dilepaskan dalam menjelaskan nominalisasi. Oleh sebab itu, telaah afiks pada bahasa Banjar sebagai lingua franca di Kalimantan merupakan kajian yang penting untuk mengenal bahasa ini lebih jauh.

\section{Metode}

Sumber data dalam penelitian ini berasal dari data lisan dan tulis. Data lisan berasal dari informan yang merupakan penutur asli bahasa Banjar. Informan juga membantu memeriksa data yang dikumpulkan. Adapun, data tulis berasal dari teks berbahasa Banjar yang diambil dari berbagai sumber, seperti buku tata bahasa, kamus, dan dokumen berbahasa Banjar.

Pengumpulan data dalam penelitian ini dilakukan dalam enam tahap. Pertama, kosakatakosakata bahasa Banjar dikumpulkan baik kelas nomina atau bukan. Kedua, data yang terkumpul 
Vol.3 No.1, 1 April 2018

diklasifikasikan dalam dua jenis, yaitu nomina dasar dan nomina turunan. Ketiga, analisis akan dilakukan pada nomina turunan pada aspek morfologis. Keempat, data akan diklasifikasikan berdasarkan bentuk dasar kosakata yang bukan berasal dari nomina. Kelima, analisis pola nominalisasi dari kosakata dasar bukan nomina. Keenam, penarikan simpulan dari data-data yang telah diklasifikasi dan dianalisis. Tahap-tahap ini dapat diamati pada gambar berikut.
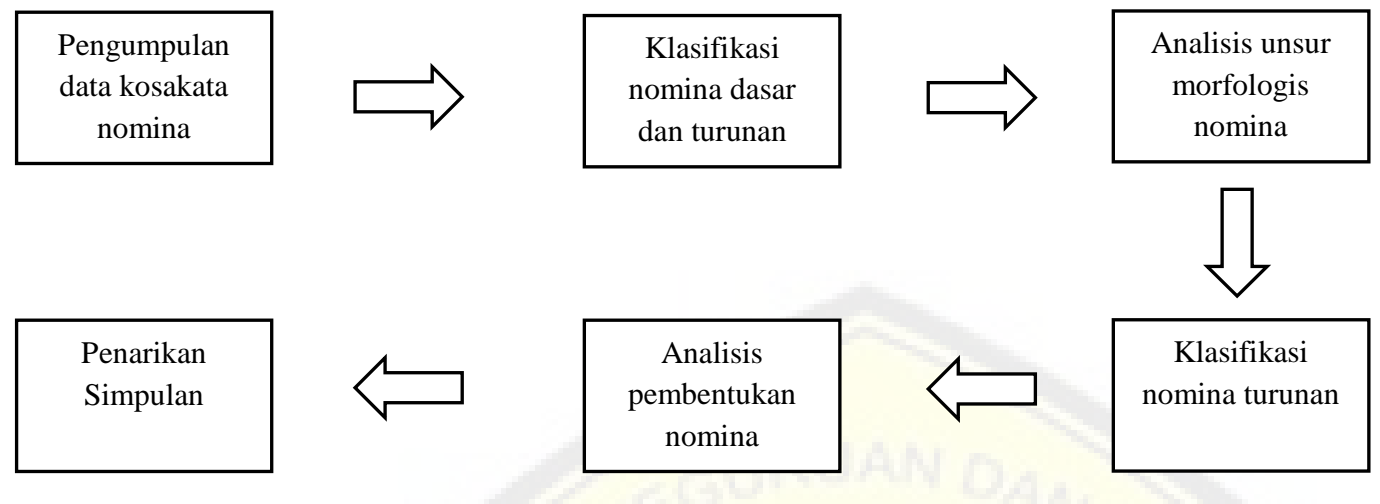

Klasifikasi nomina turunan

Gambar 1 Teknik Pengumpulan Data

Data dianalisis berdasarkan kelas kata dasar yang menjadi turunan nomina, yaitu verba, numeralia, adjektiva, dan adverbia. Pengkategorian ini digunakan karena nomina turunan dalam bahasa Banjar yang berhasil ditemukan berasal dari empat kelas kata tersebut. Afiks-afiks yang membentuk nomina berasal dari dua jenis, yaitu afiks formator derivasional dan afiks majemuk derivasional. Afiks formator adalah afiks-afiks yang membentuk kata, yaitu afiks-afiks pembentuk kata yang sifatnya mengubah kelas kata (Putrayasa, 2010: 103). Afiks formator derivasional terdiri dari prefiks dan sufiks. Afiks majemuk derivasional meliputi konfiks maupun imbuhan gabung pembentuk kata yang sifatnya mengubah kelas kata.

\section{Hasil dan Pembahasan}

Bentuk nomina terdiri dari dua jenis, yaitu nomina dasar dan nomina turunan. Nomina dasar merupakan nomina yang hanya terdiri atas satu morfem (Alwi, Dardjowidjojo, Lapoliwa, \& Moeliono, 2003: 218), sedangkan nomina turunan berasal dari proses gramatikal, yakni afiksasi, reduplikasi, dan pemajemukan. Afiksasi dalam perubahan kelas kata sangat erat kaitannya dengan derivasi dan infleksi. Derivasi adalah proses pembentukan kata yang menghasilkan leksem baru (menghasilkan kata-kata yang berbeda dari paradigma yang berbeda), sedangkan infleksi pembentukan kata yang menghasilkan bentukan kata-kata yang berbeda dengan paradigma yang sama (Purnanto, 2006: 138). 
Nomina turunan yang mengakibatkan perubahan identitas kata melalui afiksasi dalam bahasa Banjar cukup produktif. Asal perubahan ini dalam bahasa Banjar berasal dari empat kelas kata, yaitu verba, numeralia, adjektiva, dan adverbia.Pembahasannya adalah sebagai berikut.

\section{Sistem Morfologis dalam Nominalisasi Verba}

Afiks formator derivasional dalam bahasa Banjar yang membentuk verba menjadi nomina berjumlah tiga afiks, yaitu 2 prefiks dan 1 sufiks. Pembentukan verba menjadi nomina dengan bentuk prefiks, yaitu $p a$ - dan $k a$-, sedangkan suifiks, yakni -an.Selain itu, afiks majemuk derivasional, yakni konfiks juga berperan dalam pembentukan nomina. Ada dua konfiks yang mampu membentuk verba menjadi nomina dalam bahasa Banjar, yaitu ka-andan sa-an. Pembahasannya adalah sebagai berikut.

\section{1) Penurunan Nomina dengan Pa-}

Prefiks $p a$ - memiliki kemiripan dengan prefiks pe- dalam bahasa Indonesia. Prefiks ini membentuk kata dasarnya menjadi pelaku atau orang yang melakukan tindakan. Dalam bahasa Banjar, verba dapat dibentuk menjadi nomina dengan prefiks ini. Proses penurunannya dapat diamati pada contoh berikut ini.

pa+ tabas = panabas 'orang yang menebas'

pa+tatak = panatak 'orang yang memotong'

Prefiks $p a$ - dalam contoh di atas membentuk verba menjadi nomina. Kata tabas (tebas) dan tatak (potong) merupakan verba. Namun, setelah dilekati prefiks $p a$ - kata-kata itu berubah kelas kata menjadi nomina.Prefiks ini membentuk makna orang yang melakukan suatu kegiatan. Makna ini dapat dilihat pada kata panabas (penebas) dan panatak(pemotong).

Selain itu, prefiks ini juga bersifat inflektif dalam bahasa Banjar, misalnya kata gargaji yang berkelas nomina menjadi penggargaji yang berarti orang yang menggergaji. Perubahannya masih berada di kelas nomina tanpa perubahan(Humaidi, Kamariah, \& Harpriyanti, 2017: 268).

\section{2) Penurunan Nomina dengan ka-}

Prefiks $k a$ - dalam bahasa Banjar tidak ditemukan memiliki peran dalam pembentukan infleksi atau derivasi pada kelas kata lain. Contoh pembentukan verba menjadi nomina dengan prefiks ini dalam bahasa Banjar adalah sebagai berikut.

ka+ handak = kahandak 'hal ingin'

Kata ini berasal dari kata handak (ingin) yang merupakan verba dalam bahasa Banjar. Setelah dilekati prefiks $\mathrm{ka}$ - kata ini berubah kelas katanya menjadi nomina yang berarti segala sesuatu yang berhubungan dengan ingin. Kata ini dapat lebih jelas ketika digunakan dalam kalimat "Kahandak hati menukar lupis" (keinginan hati membeli lupis). 


\section{3) Penurunan Nomina dengan -an}

Sufiks -an dalam bahasa Banjar bermakna hasil dari atau sesuatu yang dihasilkan. Selain menurunkan verba menjadi nomina, sufiks ini juga memiliki sifat tidak mengubah kelas kata. Bahkan, Humaidi dkk.(2017: 270) menyatakan bahwa sufiks infleksional dalam bahasa Banjar hanya -an saja. Memang perlu penelitian lebih lanjut untuk membuktikannya, tetapi keadaan ini menunjukkan bahwa sufiks ini kurang produktif dalam bahasa Banjar bila berhubungan dengan infleksi. Sebaliknya, sufiks ini cukup sering digunakan untuk menurunkan verba atau kelas kata lain menjadi nomina. Penggunaannya dapat diamati pada contoh berikut ini.

$\begin{array}{lll}\text { gugur+ an } & \text { guguran } & \text { 'bersama-sama jatuh' } \\ \text { turun+ an } & =\text { turunan } & \text { 'bersama-sama turun/masuk sekolah' } \\ \text { bulik+ an } & =\text { bulikan } & \text { 'bersama-sama pulang' }\end{array}$

Sufiks ini membuat verba, seperti gugur (jatuh), turun (turun/masuk sekolah), dan bulik (pulang) menjadi nomina. Makna yang muncul dari pembentukan ini ialah perbuatan bersamasama. Bila dilihat dari konteks kalimat, misalnya "Guguran jambuku" yang berarti jambu berjatuhan, "Turunan esok" yang berarti esok mulai masuk sekolah, atau "Bulikan kakanakan" yang berarti anak-anak pulang bersama.

Meskipun demikian, kata ini juga dapat bersifat infleksional bila konteks kalimatnya berbeda. Peletakkan pada konteks kalimat seperti "Lakasi turunan" bermakna cepat semuanya masuk, menempatkan kata itu sebagai kalimat verba yang berarti menyuruh masuk. Begitu juga dengan kalimat "Jangan bulikan" yang bermakna jangan pulang. Kata ini tetap berstatus verba dalam kalimat ini.

\section{4) Penurunan Nomina dengan ka-an}

Konfiks ka-andalam bahasa Banjar setara dengan ke-an dalam bahasa Indonesia. Pembentukan dan maknannya juga tidak jauh berbeda. Hal ini tidak mengherankan karena bahasa Banjar dan bahasa Indonesia merupakan bahasa yang serumpun. Beberapa contoh pembentukan verba menjadi nomina yang disebabkan oleh konfiks ka-andalam bahasa Banjar adalah sebagai berikut.

$\begin{array}{lll}\mathrm{ka}+\text { liat }+\mathrm{an} & =\text { kaliatan } & \text { 'kelihatan' } \\ \mathrm{ka}+\text { gugur }+ \text { an } & =\text { kaguguran } & \text { 'kejatuhan' } \\ \mathrm{ka}+\text { lalu }+ \text { an } & =\text { kalaluan } & \text { 'tempat lalu lalang' } \\ \mathrm{ka}+\text { handak }+ \text { an } & =\text { kahandakan } & \text { 'terlalu ingin' }\end{array}$

Semua contoh tersebut berasal dari kata dasar yang tergolong verba. Kata liat bermakna lihat, kata gugur bermakna jatuh, kata lalu bermakna lewat, kata handak bermakna ingin. Setelah mengalami pembentukan dengan konfiks ka-an semuanya berubah menjadi nomina. 
Akibat perubahan ini, maknanya juga ikut berubah. Dalam bahasa Banjar,ka-an bermakna hal yang berkaitan dengan kata dasar. Kata gugur yang awalnya bermakna jatuh, berubah menjadi hal mengenai jatuh. Hal ini dapat dilihat pada contoh kalimat yang berbunyi "Mangga gugur" yang berarti mangga jatuh, sedangkan pada kalimat "Sidin kaguguran mangga" berarti beliau kejatuhan mangga. Pada kalimat ini, kata kaguguran menduduki posisi predikat, tetapi berada pada kelas kata nomina yang maknannya berarti segala sesuatu yang berhubungan dengan peristiwa jatuh.

Hal yang sama juga terjadi pada contoh ka-an yang lain. Kata kaliatan bermakna hal yang berubungan dengan lihat, seperti pada kalimat "Mun matan sini kada kaliatan" yang berarti kalau dari sini tidak kelihatan. Begitu juga dengan kata kalaluan, seperti pada kalimat "Duduk di sini kalaluan urang” yang berarti dudukan di sini merupakan tempat orang lalu lalang. Contoh yang lain juga mengalami perubahan makna yang mirip.

\section{5) Penurunan Nomina dengan sa-an}

Konfiks sa-an dalam bahasa Banjar memiliki kemampuan untuk membentuk verba menjadi nomina. Konfiks ini juga mampu mengubah kelas kata lain menjadi nomina, seperti numeralia dan adverbia. Konfiks ini memiliki kemampuan pembentukan yang paling banyak dibandingkan yang lain. Pembentukan verba menjadi nomina melalui konfiks ini dapat diamati pada contoh berikut.

\begin{tabular}{|c|c|c|}
\hline sa+tabas + an & = satabasan & 'sekali tebas' \\
\hline sa+ angkat + an & = saangkatan & 'sekali tindakan' \\
\hline
\end{tabular}

Kata dasar yang disebutkan merupakan verba. Kata tabas bermakna tebas, angkat bermakna angkat, dan tinjak bermakna tendang. Setelah mengalami afiksasi dengan konfiks sa-an semuanya berubah menjadi nomina, yaitu satabasan, saangkatan, dan satinjakan.

Perubahan makna terjadi setelah proses derivasi terjadi pada kata-kata tersebut. Makna yang muncul setelah proses ini ialah pernyataan mengenai frekuensi atau intensitas. Kata satabasan bermakna sekali tebas, seperti pada kalimat "Satabasan langsung pagat rumputnya" yang berarti sekali tebas rumput langsung putus. Kata saangkatan bermakna sekali angkat, seperti pada kalimat "Saangkatan gin lapah sudah" yang berarti satu kali angkat atau tindakan saja sudah lelah. Begitu juga dengan kata satinjakan yang bermakna satu kali tendang, seperti pada kalimat "Satinjakan ja guguran daunnya” yang berarti sekali tendang saja daun-daun jatuh. Makna yang muncul setelah mengalami derivasi pada konfiks ini ialah frekuensi tindakan yang merupakan nomina bukan lagi tindakan itu sendiri yang tergolong verba.

\section{Sistem Morfologis dalam Nominalisasi Numeralia}

Numeralia merupakan kata bilangan. Kelas kata ini setidaknya memiliki tiga ciri, yaitu dapat mendampingi nomina dalam konstruksi sintaksis, mempunyai potensi untuk mendampingi numeralia lain, dan tidak dapat bergabung dengan tidak atau sangat(Putrayasa, 2010: 
53).Pembentukan numeralia menjadi nomina cukup produktif dalam bahasa Banjar. Pembentukan ini sering ditemukan dalam percakapanberbahasa Banjar. Pembentukan ini dapat ditemukan baik pada afiks formator derivasional maupun afiks majemuk derivasional. Afiks formator derivasional ditemukan pada sufiks - an, sedangkan afiks majemuk derivasional ditemukan pada konfiks ka-nya, sa-an, dan sa-an-nya. Pembentukan itu adalah sebagai berikut.

\section{1) Penurunan Nomina dengan -an}

Sufiks - an memiliki kemampuan untuk membentuk numeralia menjadi nomina di samping fungsi derivasi yang lain. Setiap kata yang tergolong numeralia dapat dilekati kata ini. Pembentukan ini sangat mirip dengan -an dalam bahasa Indonesia. Dalam bahasa Banjar, pembentukan derivasional melalui sufiks - andapat diamati pada contoh berikut.

$\begin{array}{ll}\text { ratus+ an } & =\text { 'ratusan' } \\ \text { ribu+ an } & =\text { 'ribuan' } \\ \text { limaribu + an } & =\text { 'lima ribuan' }\end{array}$

Kata dasar dari contoh-contoh itu termasuk dalam numeralia. Namun, setelah mengalami afiksasi dengan sufiks - an,semuanya mengalami perubahan kelas kata menjadi nomina. Kata ratus menjadi ratusan, kata ribu menjadi ribuan, dan lima ribu menjadi lima ribuan.

Makna yang muncul dari proses derivasional ini ialah menyatakan nilai dari kata bilangan yang dilekatinya. Kata ribu yang bermakna nilai ribu menjadi ribuan yang bermakna bernilai sekitar ribuan. Dalam kalimat, makna ini terlihat pada teks "Ansulan sidin ribuan" yang berarti kembalian beliau berupa uang yang bernilai beberapa ribu. Makna yang muncul tidak jauh berbeda dengan dua contoh yang lain. Dengan demikian, makna yang muncul dari proses ini ialah nilai secara general dari kata numeralia yang dilekatinya.

\section{2) Penurunan Nomina denganka-nya}

Konfiks ka-nya juga dapat membentuk numeralia menjadi nomina. Konfiks ini membentuk kata bilangan menjadi kata benda yang menunjukkan kolektivitas dari objek yang ditunjuk. Berdasarkan temuan yang ada, konfiks ini hanya tampak dalam pembentukan numeralia menjadi nomina. Proses pembentukan ini dapat diamati pada contoh berikut ini.

$$
\begin{aligned}
& \mathrm{ka}+\text { talu }+ \text { nya }=\text { katalunya } \quad \text { 'ketiganya' } \\
& \mathrm{ka}+\operatorname{lima}+\text { nya = kalimanya 'kelimanya' } \\
& \text { ka+ sapuluh + nya = kasapuluhnya 'kesepuluhnya' }
\end{aligned}
$$

Kata bilangan yang disebutkan berubah menjadi nomina, sebagaimana kata talu menjadi katalunya, kata lima menjadi kalimanya, dan sapuluh menjadi kasapuluhnya. Konfiks ini dapat melekat pada semua kata bilangan yang ada dengan makna yang sama.

Makna yang muncul dari penurunan ini ialah semua jumlah yang disebutkan pada kata bilangan. Misalnya pada kalimat "Kalimanya manukari baju ikam" yang berarti lima-limanya 
membeli bajumu. Kata kalimanya menunjukkan bahwa semua dari lima orang disebutkan melakukan tindakan yang sama.

\section{3) Penurunan Nomina dengan sa-an}

Konfiks sa-an selain membentuk verba juga memiliki kemampuan membentuk numeralia menjadi nomina. Bahkan, konfiks ini juga bersifat inflektif pada lingkup nomina dan adjektiva (Humaidi dkk., 2017: 262)Bentuk ini mirip dengan sufik -an, tetapi konfiks ini menunjukkan satuan jumlah. Pembentukan ini dapat dilihat pada contoh berikut ini.

$$
\begin{array}{lll}
\mathrm{sa}+\mathrm{ratus}+\mathrm{an} & \text { = saratusan } & \text { 'sekitar ratusan' } \\
\mathrm{sa}+\mathrm{ribu}+\mathrm{an} & =\text { saribuan } & \text { 'sekitar ribuan' } \\
\mathrm{sa}+\mathrm{juta}+\mathrm{an} & \text { = sajutaan } & \text { 'sekitar jutaan' }
\end{array}
$$

Kata dasar yang disebutkan merupakan numeralia, yaitu kata ratus, ribu, dan juta. Meskipun demikian, setelah terbentuk dengan konfiks sa-an menjadi saratusan, saribuan, dan sajutaan. Pembentukan ini hanya melekat pada satuan jumlah, seperti puluhan, ratusan, ribuan, jutaan dan seterusnya. Adapun kata satuan, seperti satu, dua, tiga, dan seterusnya tidak bisa dilekati konfiks ini.

Makna yang terbentuk dari konfiks sa-an dalam bahasa Banjar ialah satuan jumlah. Pada kata saratusan bermakna satuan jumlah pada tingkat ratusan. Hal ini terlihat pada kalimat "Duit nang dijulung sidin saratusan haja” yang berarti uang yang diserahkan beliau bernilai ratusan saja. Kata seratusan itu bermakna jumlah satuan ratusan.

\section{4) Penurunan Nomina dengan sa-an-nya}

Pembentukansa-an-nya tergolong sebagai imbuhan gabung. Afiks ini merupakan pembentukan dari konfiks sa-andan sufiks-nya. Afiks ini dapat dilekatkan dengan numeralia dalam bahasa Banjar dan membentuk nomina. Hal ini dapat diamati pada contoh berikut ini.

$$
\begin{array}{ll}
\text { sa }+ \text { ikung }+ \text { an }+ \text { nya }=\text { saikungannya } & \text { 'hanya satu' } \\
\text { sa }+ \text { bigi }+ \text { an }+ \text { nya }=\text { sabigiannya } & \text { 'hanya sebiji' }
\end{array}
$$

Kata dasar yang disebutkan merupakan numeralia, yaitu ikung yang berarti ekor dan bigi yang berarti biji. Setelah terbentuk dengan imbuhan gabung sa-an-nya berubah menjadi nomina, yaitu saikungannya yang bermakna hanya satu ekor dan sabigiannya yang bermakna hanya satu biji.

Makna yang muncul dari pembentukan ini ialah batas atau jumlah dari kata dasar yang dilekati. Misalnya kata saikungannya pada kalimat "Sidin saikungannya mambil iwak” yang berarti beliau hanya mengambil satu ikan. Begitu juga kata sabigiannya pada kalimat "Aku nukar kustila sabigiannya" yang berarti saya membeli papaya hanya satu biji. Kata saikungannya dan sabigiannya menunjukkan bahwa jumlah yang disebutkan pada kalimat itu terbatas hanya satu saja. 


\section{Sistem Morfologis dalam Nominalisasi Adjektiva}

Adjektiva atau yang lebih dikenal dengan kata sifat memberikan keterangan terhadap nomina dengan fungsi atributif. Adjektiva akan menunjukkan kualitas dari nomina. Penurunan nomina dari adjektiva bahasa Banjar diakibatkan oleh prefiks $p a-$. Dalam menurunkan adjektiva, afiks ini tidak jauh berbeda ketika digunakan pada verba bila diamati dari segi semantik. Keduanya menghasilkan makna pelaku atau orang yang memiliki kualitas sifat kata tersebut. Hal ini terlihat pada contoh berikut.

$\begin{array}{lll}\mathrm{pa}+\text { lapah } & =\text { palapah } & \text { 'orang yang mudah lelah' } \\ \mathrm{pa}+\text { palar } & =\text { pamalar } & \text { 'orang yang pelit' }\end{array}$

Katapalapah dan pamalar tergolong kata sifat yang berasal dari kata lapah (lelah) dan palar (pelit). Kata-kata itu berubah menjadi nomina sehingga menghasilkan makna pelaku atau orang yang mempunyai sifat. Kualitas sifat yang dihasilkan dari prefiks ini masih dalam tingkat normal. Akan tetapi, bila adjektiva mengalami proses afiksasi dengan konfiks pa-nya, kualitas sifat yang dihasilkan menjadi superlatif. Contohnya adalah sebagai berikut.

$\mathrm{pa}+$ lapah + nya $\quad$ = palapahnya 'orang yang paling lelah'

pa + palar + nya = pamalarnya 'orang yang paling pelit'

Namun, bentuk ini bukan tergolong nomina bila mengacu ciri nomina yang mengharuskan kemampuan kata tersebut memenuhi tiga ciri, yaitu menduduki fungsi subjek objek, atau pelengkap; dapat diingkarkan dengan kata kada (tidak), tetapi lain (bukan); dan dapat diikuti oleh adjektiva (Alwi dkk., 2003: 213). Kata tersebut tidak memiliki ciri ketiga yakni kemampuannya diikuti adjektiva secara langsung atau tidak langsung dengan kata nang (yang).

Adjektiva dalam bahasa Banjar lebih mengarah pada infleksi daripada derivasi. Sebagaimana temuan Humaidi dkk. (2017: 262) pada lingkup adjektiva, afiks infleksi mencapai delapan jenis, yaitu prefiks infleksi berjumlah 3 buah, yaitu $m a$-, $t a$-, dan $p a-$, sufiks 1 buah, yaitu -an, dan konfiks berjumlah 4 buah, yaitu sa-an, pa-an, pa-nya, dan ka-an. Oleh sebab itu, sangat sulit menemukan afiks yang menurunkan adjektiva menjadi nomina dalam bahasa Banjar.

\section{Sistem Morfologis dalam Nominalisasi Adverbia}

Adverbia sering disamakan dengan kata keterangan, padahal keduanya berbeda. Adverbia merupakan konsep kategori, sedangkan keterangan merupakan konsep fungsi. Adverbia dapat ditemukan dalam bentuk dasar dan bentuk turunan. Pembentukan adverbia menjadi nomina dalam bahasa Banjar hanya ditemukan pada konfiks sa-an. Hal ini dapat dilihat pada contoh berikut ini.

$\begin{array}{lll}\text { sa }+ \text { kamarian }+ \text { an } & \text { = sakamarianan } & \text { 'satu sore penuh' } \\ \text { sa+ harian }+ \text { an } & =\text { saharianan } & \text { 'seharian penuh' } \\ \text { sa+ malam }+ \text { an } & \text { = samalaman } & \text { 'semalam penuh' }\end{array}$


Kata dasar yang tergolong sebagai adverbia pada contoh itu, yaitu kamarian yang berarti sore, hari yang berarti hari, dan malam yang berarti malam mengalami pembentukan menjadi nomina setelah dilekti konfiks sa-an. Kata-kata itu menjadi sakamarianan, saharianan, dan samalaman.

Makna yang muncul dari pembentukan derivasional ini ialah satuan dari kata dasarnya. Pada kata sakamarianan makna ini terlihat pada kalimat "Kami mamasak sakamarianan di dapur” yang berarti kami memasak selama satu sore penuh di dapur. Pada kata saharianan makna ini terlihat pada kalimat "Buhannya manggawi saharianan” yang berarti mereka mengerjakan selama satu hari penuh. Begitu juga dengan kata samalaman pada kalimat "Sidin kada baguringan samalaman" yang berarti beliau tidak tidur satu malam penuh. Kalimat-kalimat itu menunjukkan bahwa kata dasar yang dilekatinya menunjukkan satuan secara penuh bukan hanya sebagian saja.

\section{Simpulan}

Afik pembentuk nomina dalam bahasa Banjar cukup kaya karena memiliki kemampuan mengubah empat kelas kata lain, yakni verba, numeralia, adjektiva, dan adverbia. Verba dan numeralia merupakan kelas kata yang paling bervariasi dalam berubah menjadi nomina, sedangkan adjektiva dan adverbia kurang bervariasi dalam membentuk nomina melalui afiksasi. Afiks yang berperan dalam nominalisasi verba berjumlah lima buah, yaitu prefiks pa- dan ka-, sufiks -an, dan konfiks ka-an dan sa-an, sedangkan afiks yang berperan dalam nominalisasi numeralia berjumlah empat buah, yaitu sufiks -an dan konfiks ka-nya, sa-an, dan sa-an-nya. Adapun afiks yang menurunkan adjektiva dan adverbia menjadi nomina hanya satu afiks masing-masing, yaitu prefiks pa- pada adjektiva dan konfiks sa-an pada adverbia.

Penurunan nomina dari berbagai kelas kata dalam bahasa Banjar menunjukkan bahwa derivasi merupakan proses yang sering terjadi dalam penuturan atau penulisan bahasa Banjar, selain infleksi. Hal ini mengindikasikan bahwa derivasi merupakan proses yang kaya dalam bahasa ini sehingga perlu ditelaah lebih jauh dengan mengkaji penurunan pada kelas kata yang lain.

\section{Daftar Pustaka}

Alwi, H., Dardjowidjojo, S., Lapoliwa, H., \& Moeliono, A. M. 2003. Tata Bahasa Baku Bahasa IndonesiaEdisi Ketiga. Jakarta: Balai Pustaka.

Bustam, M. R., \& Juanda. 2014. Nominalization Strategies of exclusion Represented on The Headlines of The Jakarta Post in The Case of Feud of KPK vs Polri Part II : A Study of CDA. Metalingua, 12(2), 195-204.

Fatonah. 2014. Students' Understanding of The Realization of Nominalizations in Scientific Text. Indonesian Journal of Applied Linguistics, 4(3), 87-98.

Garnida, S. C., \& Mirahayuni, N. K. 2012. Syntactic and Semantic Analysis of Nominalization in 
English Academic Writing. Parafrase, 12(1), 1-10.

Humaidi, A., Kamariah, \& Harpriyanti, H. 2017. Infleksi dalam Bahasa Banjar. Stilistika: Jurnal Bahasa, Sastra dan Pengajarannya, 2(2), 262-272.

Jalilifar, A., White, P., \& Malekizadeh, N. 2017. Exploring Nominalization in Scientific Textbooks: A Cross-Disciplinary Study of Hard and Soft Sciences. International Journal of English Studies, 17(2), 1-20. https://doi.org/10.6018/ijes/2017/2/272781

Purnanto, D. 2006. Kajian Morfologi Derivasional dan Infleksional dalam Bahasa Indonesia. Kajian Linguistik dan Sastra, 18(35), 136-152.

Putrayasa, I. B. 2010. Kajian Morfologi (Bentuk Derivasional dan Infleksional). Bandung: PT Refika Aditama.

Saryana, I. W. 2017. Nominalisasi Bahasa Bali. Kulturistik Jurnal Bahasa \& Budaya, 1(1), 86-96.

Suhardi. 1984. Transformasi Nominalisasi Bentuk Verbal Bahasa Indonesia dalam Pengajaran Bahasa. Cakrawala Pendidikan, 3(12), 188-201.

Zainuddin. 2016. Sistem Nominalisasi Bahasa Gayo: Kajian Struktur dan Semantik. Linguistika, 23(45), 110-120.

Zakaria, U. 2018. Nominalisasi Verba Bahasa Buol. DalamSeminar Nasional Pakar ke-1 (pp. 131137). 